\title{
OPPORTUNITY FUNDING CORPORATION: AN ANALYSIS
}

\author{
Samued I. Doctors* and Sharon Lockwood $\dagger$
}

The Opportunity Funding Corporation's primary novelty is that it is the first attempt to determine experimentally how to build a capital base in low-income communities. It attempts, in effect, to transfer the experience and learning of the banker, the securities analyst, and all the other financial specialists who help to create the money markets and the investment opportunities that leverage the use of capital in this country. It is thus an attempt to experiment in the transfer of financial technology from the affuent, capital-rich economy of Wall Street to the poor, capitalstarved economy of the urban and rural ghettos and barrios. It may, of course, be inappropriate to suppose that the financial technology common in the non-minority community can or should be transferred to the minority community.

The Opportunity Funding Corporation (OFC) was born in controversy, and it has been initiated in spite of substantial protest by the very groups it seeks to serve. Officially, OFC is an experimental economic development effort designed to test and demonstrate the effectiveness of various incentive, guarantee, and rediscount techniques in attracting private capital to low-income areas. Unofficially, the new program has been labeled by some community leaders as a white-run boondogglejust a new way of taking money away from the poor and giving it to non-minority capitalists. ${ }^{1}$ Reverend Douglas Moore of Washington's Black United Front has called OFC "an example of OEO money wasted on a white-run "phony outfit." "2

There is a requirement that the local Community Action Program (CAP) agency must approve OEO anti-poverty grants in the Washington area. The Washington anti-poverty agency, the United Planning Organization (UPO), which was the agency responsible for approving the initial OFC grant, refused to do so. The

- Associate Professor of Management Environment, Northwestern University Graduate School of Management. Professor Doctors acted as a consultant to Ted Cross during the development phase of OFC, and he is the editor of the Report of the President's Advisory Council on Minority Business Enterprise.

†Economic Advisor to the President's Council on Minority Business Enterprise; Financial Economist, Small Business Administration.

Much of the material presented in this paper was gathered during the course of the authors' work with Ted Cross, officials at OEO, members of the OFC Board of Directors, and staff members of the President's Council. However the views presented are only those of the authors and do not necessarily reflect the views of any other individual or organization.

${ }^{1}$ See Rosenthal, Investment Test is Slated by OEO, N.Y. Times, Mar. 22, I970, $\$$, at 53, col. 3; Office of Economic Opportunity, Fact Sheet on the Opportunity Funding Corporation: Description and PuRPose (1970); Office of Economic Opportunity, Opportuntty Funding: AN Economic Development Demonstration Program (1970).

'Bowman, Poverty Agencies Quarrel Over Black Capitalism Plan, Washington Post, Aug. 18, 1970, at C-I to C-20. 
reason given by UPO officials was that the project was "unworkable, would cost too much money, and might compete here in Washington with UPO itself."3

Rev. Moore and other community leaders complained of the vagueness of the proposal to OEO. Nationally, a fairly broad spectrum of community leaders have also expressed the feeling that OFC was set up in secrecy and without any real input from the very community groups it was intended to serve. On the other hand, Eli Goldston, a member of the OFC Board of Directors, and former OEO Administrator Donald Rumsfeld felt the proposal for funding had to be worded vaguely in order to give the experimental program the necessary freedom in planning and operation. ${ }^{5}$ Mr. Rumsfeld also felt that there was some urgency in launching the OFC project and that inputs from the various community groups would be useful in shaping OFC programs after the project was in operation.

Why so much protest against an organization that on paper sounds like a cross between a Harley Street banking house and a Hartford-based insurance company? Why have community leaders been so vociferous in their opposition to the OFC concept and to OEO's efforts to establish it? Why have many financial and business leaders been so enthusiastic in their response?

The answers to the questions of why the protest and why the enthusiasm are not hard to find. The protest arose from the way the OFC concept was formulated and established as an operating entity. The enthusiasm was the result of the OFC philosophy of minority economic development which is largely a "business" approach to such development. To understand both the protest and the enthusiasm it is necessary to examine the brief history of OFC and its creator's philosophy of minority development.

HisTORY

A. The Formative Concepts

OFC officially became an entity in June of I970 when it was incorporated as a non-profit corporation under the laws of Delaware. For months before the incorporation, the concept had been in the development process at OEO. In the fall of I 69 , Donald Rumsfeld, then Administrator of the Office of Economic Opportunity, asked Ted Cross, who was later to become the author of the OFC concept, to come to Washington to develop a program based on his book, Black Capitalism. ${ }^{\circ}$ Cross, a New York City attorney and an expert on banking law, decided to under-

\footnotetext{
Id.

- See Office of Economic Opportuntty, The Opportunity Funding Corporation Statement of Work ( $\mathrm{x} 970)$. This document was initially drafted by Theodore Cross and reworked by OEO officials, and consists of a forty-three page description of the proposed OFC program. It does not state explicitly which projects OFC would undertake; rather it describes a variety of possible projects and generally describes the concepts underlying the OFC program.

s Bowman, supra note 2.

T. Cross, Black Capitalism (1969).
} 
take the project on a half-time basis as a consultant to OEO. He maintained his law practice and other business interests in New York City on a restricted basis for the duration of his work in Washington. He was supplied with three secretaries, an aide who was a White House Fellow and several offices at OEO headquarters. He spent the next six months working with a few Rumsfeld aides in designing a program that would pass bureaucratic inspection. He also talked with scores of business and financial leaders, minority businessmen, government officials, and academicians. The result was OFC.

Cross argued that there will never be enough money available to fund minority economic development programs from government sources alone and that ways and means must be found to substantially leverage the resources from standard money markets. He further argued that only by inducing such substantial private sector investment of resources and expertise can sufficient effort be brought to bear on the problem. The rationale for these arguments had been developed earlier while he was writing his book on black capitalism.

The major thesis of the Cross book is that the ghetto economy does not obey the rules of the larger economy. Cross argues that credit, at a reasonable cost, is unavailable in the ghetto, that savings as a source of equity capital are almost nonexistent, and that the ghetto entrepreneur is a "missing person." Many of the incentives which would promote business and economic development are missing. The full magnitude of the problem must first be understood before any action can be taken to remedy the situation. Cross states that viewing the ghetto as merely a reflection of the larger society has, in the past, only provided palliatives as a solution and that such palliatives have had no long-term impact on getting at the root cause of ghetto poverty. ${ }^{7}$

Cross maintains that fifteen million or more black people live in $x 6_{3}$ isolated slums whose economics are fundamentally structured to prevent the accumulation of wealth because they:

(x) are inhospitable to investment or technical assistance;

(2) have little motivation to save or convert even available savings to venture capital;

(3) have little or no entrepreneurial opportunity in legitimate business; and

(4) are isolated from the mainstream economy by a series of tariffs on retail sales, rents, and credit, but are totally dependent on imports from the mainstream economy for most of their basic goods and services. ${ }^{8}$

Cross feels that the economic system of the ghetto economy militates against traditional programs of poverty aid or charity as a vehicle for change. He also concludes that the federal government has been unable to demonstrate competence

${ }^{7} I d$. at $2 \mathrm{I}-69$.

${ }^{8}$ Id. at 204-05; but see J. Duesenberry, Income, SAVING, and the Theory of Consumer Behavior 50-52 (I949) for a quite different view of the motivation for savings and investment. See also pp. 17-68 for a general theoretical discussion. 
in implementing effective anti-poverty programs. Thus he advocates a system of federal incentives, guarantees, equity insurance, rediscount arrangements, and subsidies which will induce a massive infusion of private sector capital and know-how into the ghettos to create viable capital creation and retention institutions. This new system of incentives, guarantees, and subsidies must be structured to provide a compelling reason for private investment, not one based primarily on charity or guilt feelings.

\section{B. Formation of OFC}

The early OFC developmental work at OEO was dubbed "Project X." Project $X$ went through a number of written drafts which were carefully circulated to a select group within the agency. Circulation was limited to less than ten copies of the document. The document consisted of a hypothetical press conference by Rumsfeld explaining the nature and purpose of OFC, a functional description of the OFC organization, and a series of possible experimental projects. Many of these experimental projects were added by Mr. Cross after discussions with a number of businessmen, financiers, community leaders, academicians, and governmental officials.

It was decided that OFC would take the form of a non-profit corporation whose funding would come largely from title I-D Special Impact Funds. ${ }^{10}$ It was felt that OFC should be relatively independent of the government in order to have more freedom to experiment. To help insure this independence a highly prestigious board of directors was assembled:

Dr. David Hertz, Chairman

(elected October, I970)

Director, McKinsey \& Co.

New York, New York

Eli Goldston

Chairman and Chief Executive Officer

Eastern Gas \& Fuel Association

Boston, Massachusetts

Alex Mercure

State Project Director, Project HELP

Albuquerque, New Mexico
Rev. Leon Sullivan

President and Founder

Opportunities Industrialization Center

Philadelphia, Pennsylvania

Dr. Robert Vowels

Dean, School of Business Administration

Atlanta University

Atlanta, Georgia

Robert O. Dehlendorf, II

President, Arcata National Corporation

Menlo Park, California

\footnotetext{
${ }^{\circ}$ In his The Age of Discontinuity, Peter Drucker has generally concluded that federal government programs in such social areas as poverty and education have largely failed because government is not equipped to implement or carry out programs. Thus Drucker, like Cross, advocates a restructuring of federal programs to require the government to provide the overall strategy and financial incentives, while the implementation is left to the private sector. P. Drucker, THE AGE of Discontrnurty 212-42 (1968).

${ }^{10}$ See description detailed in note 12 infra.
} 
John Mabie

Vice-President and Director

A. G. Becker and Company

Chicago, Illinois

James M. Hall

Secretary, Business and Transportation

Agency

State of California

Sacramento, California
Dan Lufkin

Chairman, Executive Committee

Donaldson, Lufkin, \& Jenrette

New York, New York

The board is divided fairly evenly between Republicans and Democrats. It contains three minority group members and is headed by David Hertz. Names of board members were solicited from a variety of sources, both inside and outside of government. The major criteria, aside from political considerations, were a history of active participation in minority economic development, clout in the corporate world or in minority communities, and a willingness to devote substantial amounts of personal time to OFC. Every candidate was cleared through the White House, and several potential candidates were dropped because they were unacceptable to the White House. However, the White House was liberal in its view of candidates' political orientation and four of the first five appointments were Democrats.

It was decided that most of the programs would be channeled through the OEO-initiated and supported community development corporations (CDC's). This decision was made, in part, to mute pressures exerted by the CDC's against the establishment of OFC. Community development corporations draw their principal support from title I-D funding and were not pleased at the prospect of competing with OFC for limited funds. ${ }^{11}$

Little thought was given to possible alternatives or supplementary sources for OFC funding from other government agencies. It was assumed that most of the funding for the forseeable future would come from OEO title I-D research and demonstration appropriations and from public offerings of OFC securities, "Opportunity Bonds." Cross contemplated that OFC would acquire significant independence and power if it could market Opportunity Bonds in public markets. Initial funding of OFC was pegged at about $\$ 20$ million, but only $\$ 7.4$ million actually was made available. ${ }^{12}$ Approximately one half came from title I-D funds and half from research

\footnotetext{
${ }^{21}$ Approximately \$10.6 million was available in fiscal 1969 and $\$ 31.2$ million in fiscal I970 from title I-D. Fifteen existing CDC's and 21 new CDC's received title I-D funds in fiscal x970. Thus, less than an average of $\$ \mathrm{I}$ million was available per CDC in fiscal I970. Department of CoMmerce, Report to the President on Minority Business Enterprise, at III-32 to III-33 (I970).

${ }^{13}$ An OEO news release (June 30,1970 ) indicated that the newly created non-profit OFC was incorporated in Delaware and would have its principal offices in Washington, D.C. Its initial funding of \$7.4 million would come from title I-D (\$3.9 million) and from research and development funds (\$3.5 million). "Title I-D" refers to the section in the OEO Act of 1964 which provides development funds for "special impact areas." What the news release did not say is that OFC was originally to have received more than $\$ 20$ million in first year funds. But internal pressures at OEO and pressures
} 
and demonstration funds. ${ }^{13}$

In addition to the board of directors, the corporation was to have a president and a small professional staff, perhaps three to five in number most of whom were minority group members. ${ }^{14}$ Although OFC was incorporated in June, $x 969$, little was done to find a president until the fall of 1970 when David Hertz engaged a private consulting firm to assemble a list of potential candidates. By October, the list had been reduced to eight candidates, each of whom was to be interviewed by members of the board. In late November, the decision was made to name John Gloster of the Urban Coalition as the first president of the OFC.

Mr. John Gloster presented his initial plan to the board in December, and three of the OFC pilot projects are currently underway: (I) surety bonding for minority contractors in cooperation with black and Chicano contractors in Los Angeles, and with black contractors seeking a substantial part of the Metro transit program in the District of Columbia; (2) consumer credit for low-income citizens, including those on welfare and those unemployed, in cooperation with the National Congress for Community Economic Development and community development corporations and their constituents; and, (3) supplementary funding for low-income area minority lending institutions. ${ }^{15}$

\section{II}

\section{Operation of OFC}

\section{A. Components of the Opportunity Funding Corporation}

OFC has three principal components: Opportunity Guarantee, Community Development Discount, and Incentive Simulation (figure I). The first component, Opportunity Guarantee, is designed to reduce the aversion of private institutions to committing capital and credit to low-income communities by providing a variety of guarantees. It will operate only when comparable guarantees are not available from existing federal, state, or private sources and where the perceived risk is quite high. The second component, Community Development Discount, is designed to demonstrate the feasibility of establishing a secondary market for SBA- and EDAbacked obligations and other commercial paper generated in low-income communities. It will purchase this paper, repackage it, and resell these new securities with a guarantee to such institutions as pension funds, churches, and others seeking a safe, yet socially useful investment opportunity. This guarantee will be similar to that of the Federal National Mortgage Company in the mortgage market. It

from the community development corporations led to the cutback of almost two-thirds of the original pledge amount.

${ }^{18}$ Initially, when the funding was to have been more than $\$ 20$ million, it was thought that the staff might have to be considerably larger than the presently planned four or five professionals. One of the authors had been asked to design an organization structure for this larger organization.

16 Profirs, Jan., I97r, at 3 (monthly newsletter of the Institute for Minority Business Enterprise, Howard University).

${ }^{15}$ Id. 
is designed to test whether such a facility can provide substantially increased liquidity for lending institutions serving low-income communities.

In briefings Cross always emphasized that the great gamble of $\mathrm{OFC}$ was that development in ghettos, barrios, and reservations could ultimately become selffinancing. He argued that historically bankers have always been wrong-that the nonbankable goals of today always become the solid collateral of tomorrow. He urged the analogy of the World Bank which is currently making development loans to fund housing and health care for the poor of East Pakistan and other underdeveloped nations.

The third component, Incentive Simulation, is intended to test various incentives, such as simulated tax incentives, to promote private investment in disadvantaged communities. Of course, OFC is not organized with these three distinct elements, and one staff member may be responsible for projects in several component areas.

FIGURE I

\section{OFFICE OF ECONOMIC OPPORTUNITY}

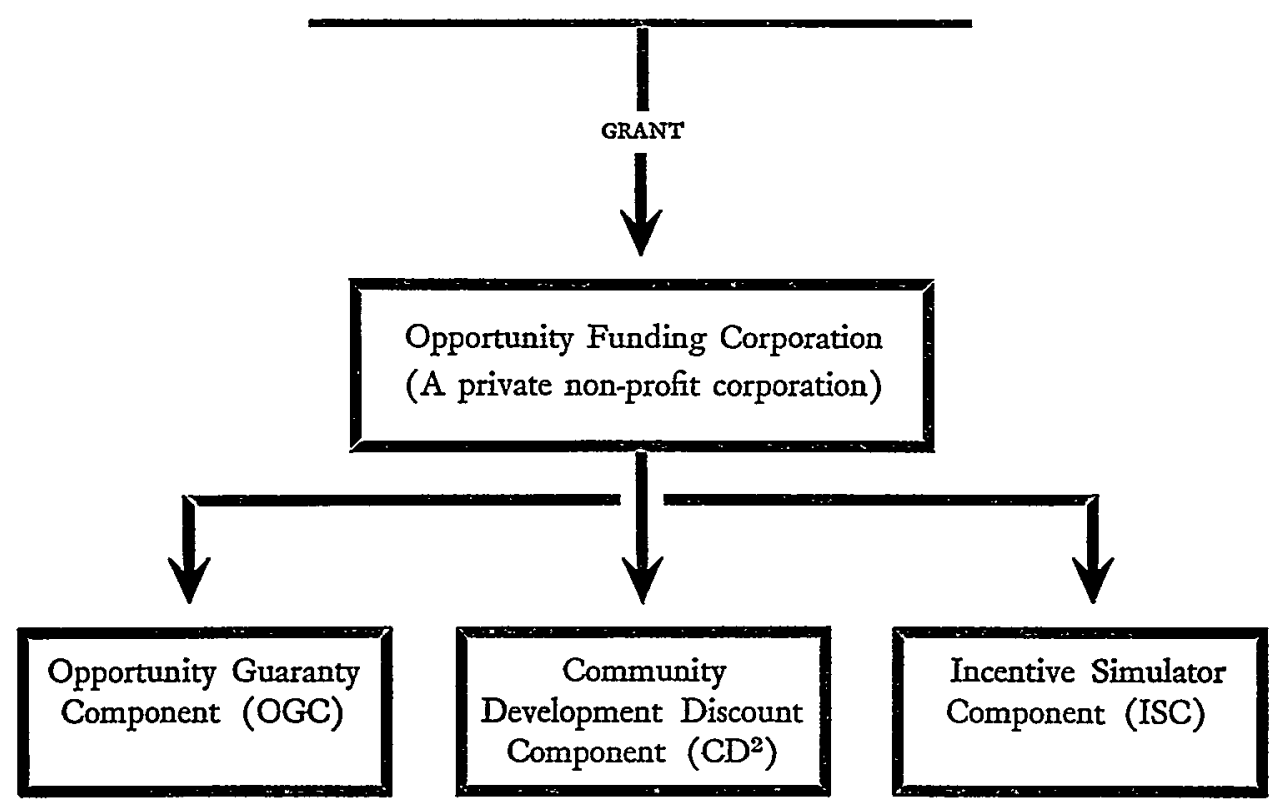

Source: OEO, Opportunity Funding: AN Economic Development Demonstration Program (I970).

\section{B. OFC-A Demonstration Vehicle}

It is important to understand OFC as one of the very few minority economic development programs which has the full support of the Nixon Administration. On several occasions Cross presented the OFC program to the White House staff and, in March, I970, to President Nixon and the full Cabinet. OFC seeks to apply the traditional techniques of financial leveraging to minority economic development. It 
is not a welfare program; it is not meant to provide outright grants; rather it seeks to use modest sums of government money to attract large sums of private capital into the nation's rural and urban ghettos and barrios.

$\mathrm{OFC}$ is not truly an operating arm of the federal government, rather it is a test and demonstration vehicle like its parent organization, OEO. Its stated purpose "is to test the effectiveness of various incentive techniques in attracting private sources of money to rural and urban low-income areas." Each of the pilot projects is designed to establish a specific need for legislative and/or administrative changes. Thus the OFC has chosen four criteria for the selection of projects for funding:

x. The project must be innovative in concept and must provide leverage for OFC's investment.

2. The project must have national impact, as distinguished from meeting a local economic need under specialized circumstances.

3. The project must be capable of being reproduced in other localities.

4. The project must have demonstrable benefits for poverty area residents. ${ }^{10}$

\section{III}

\section{Potential Problems}

Ted Cross is a consummate technician. He knows the art of finance and the related areas of law, but he was unaware of the intricacies of governmental agencies or community development politics. He also was unaware of the need to cultivate various members of the OEO bureaucracy as well as community development leaders who would be most affected by OFC. Donald Rumsfeld, Cross' leading backer, assumed that OFC could be conceived and set into motion with only minimal interface with community leaders or with OEO's own internal departments. Rumsfeld did check out the OFC concept with a number of influential persons such as McGeorge Bundy, President of the Ford Foundation. However, the failure to fully inform those most directly affected by OFC, such as the CDC's and other community development groups, has resulted in substantial criticism both inside and outside $\mathrm{OEO}$, often more because of ignorance of the proposed program rather than genuine criticism of its substance. In private, most community leaders are enthusiastic about the OFC concept and few OEO staff members can be found to argue against the substance of the OFC program.

The original framework for restructuring ghetto economies presented by Cross in Black Capitalism assumed a massive simultaneous onslaught on many fronts such as designing programs to reduce the risk on "soft" commercial loans, developing a secondary market for ghetto installment paper, stimulating deposits in slum area banks, establishing special ghetto development banks, increasing the amount of capital available for ghetto ventures, and planning other programs to develop and

\footnotetext{
${ }^{10}$ Id.
} 
train ghetto entrepreneurs. ${ }^{17}$ Although not explicitly articulated, it is apparent that Cross assumed that the synergy developed by these various complementary programs would provide a critical mass for significant change. While economists are not entirely clear about all the prerequisites for economic development in underdeveloped areas, it is fairly clear that such development requires the interaction of many individual components to achieve significant growth.

OFC, on the other hand, proposes to initiate at most one or two experiments in any one ghetto area. Thus, these experiments are not likely to be more than a pale shadow of the real capital base-building and leveraging techniques commonly used in the larger economy, which depend for their success on the existence and interaction of a whole series of financial and business institutions. OFC has very limited resources, only $\$ 7.4$ million for the first year of operation, which would not even provide the capital for one medium-sized development bank. OFC will have to concentrate on a limited number of projects in a relatively small number of poverty areas and thus will not be able to really simulate an overail economic development program in any community.

There is the very critical question of measurement of results. What can be measured and over what period of time? Donald Rumsfeld in the hypothetical Project X press conference says, "The guaranty and loan discount arrangements should prove out quite quickly. In six months we'll know if inner city CDC's and others are using our new facilities. It will probably be another year before we will know about our costs, which are overhead plus bad debt experience. The tax simulations will take longer. We should know a lot in a year."18 Given the complexity of the development process generally, along with the additional problems of operating in a ghetto environment, it would seem that Rumsfeld's optimism is scarcely justified. Mere use by CDC's or other community groups is hardly proof of the relative success of OFC experiments. These groups may use OFC simply because it represents an additional source of funding, not because they foresee any long-term economic benefit to themselves or to the community. Nor is it clear that measurement of usage is any indication of the capital base building potential of any particular item in the OFC repertoire.

Another important problem is the fact that the OFC may be continually in the spotlight, subject to political pressures from a variety of sources. These pressures are likely to require that OFC produce immediate, visible successes. The initial projects must be successful, at least in terms of what can be easily measured, such as the number of users of OFC services or the number of dollars attracted into a particular project. Such measures, however, may not indicate the eventual importance of OFC experiments. ${ }^{19}$ Economic development is a long-term process

\footnotetext{
${ }^{17}$ T. CRoss, supra note 6, at 159-209.

${ }^{18} \mathrm{~T}$. Cross, Project X, Mar. IO, I970, at 9-Io (unpublished OEO memorandum).

${ }^{10}$ For a discussion of the difficulties of measuring the results of CDC programs, see M. Brower, The Criteria for Measuring the Success of a Community Development Corporation in the Ghetto, Mar., I970 (unpublished paper in Cambridge Institute).
} 
and as such is not likely to yield much in the way of early success stories. In fact, it may be necesary to sacrifice early numerical usage figures for long-term impact. ${ }^{20}$

OFC is at present in direct competition for funds with the various CDC's. This has already created substantial hostility to the concept of OFC. Thus OFC must prove, fairly rapidly, that it does in fact make it possible to leverage CDC funding, or else it will come under increasing attack from the CDC's.

Another substantial problem area is that of transferring the results of "successful experiments" to operating agencies. No one at OEO considered in detail the problems entailed in transferring the results of OFC experiments to the various domestic affairs agencies involved in development, such as the Small Business Administration, the Department of Agriculture, and the Economic Development Administration in the Department of Commerce. Cross did give briefings to a number of agencies and departments, but no real study has been made of the transfer problem. Of course, in those cases requiring legislation, the appropriate congressional committee must be involved early in the experimental process. There is substantial literature available in the information transfer area, most of which indicates the complexity of transferring information across institutional lines. ${ }^{21}$

Continued funding is likely to be a problem, given the general congressional and Administration disposition to cut back on OEO funding. There also will be problems clearing new funding through OEO itself, as OFC fund proposals must compete with numerous other applicants for very scarce economic development funds.

In addition, there is a built-in tension between the desire of OEO to control OFC experiments to maximize their value in terms of OEO goals and objectives and the desire of OFC to operate as an independent entity free to choose experiments from its own agenda. In the initial contract negotiations between OEO and OFC, there was a considerable amount of friction over the degree to which OEO would control experiments. Several board members indicated their unhappiness with what they saw as OEO's attempt to maintain a veto power over OFC operations. This issue was vigorously debated over a period of several weeks before the initial contract was signed, and it is still in doubt. OEO has historically been cited by a number of grantee institutions as unduly officious in the conduct of funded research. ${ }^{22}$ On the other hand, OFC does represent the principal vehicle for domestic development experimentation and is therefore of great importance to the success

${ }^{20} \mathrm{~A}$ similar problem was presented for NASA in its spinoff program with its need to produce quickly tangible examples of technology transfer. This emphasis on producing quick success in a very complex problem area may have been the single most important reason for the failure of the NASA transfer program. For a discussion of this similar measurement problem area, see S. Doctors, The Rolv of the Federal Agencies in Technology Transfer (ig69).

${ }^{21}$ See, e.g., E. Rodgers, Diffusion of Innovation (1962); S. Doctors, supra note 20; J. Jewkes, D. Sawers, \& R. Stilleracan, The Sources of Invention (I958).

22 The issue of unduly restrictive federal agency contract terms and administration is discussed in Staff of Research and Technical Problems Subcomm. of the House Comm. on Gov't Operations, 9oth Cong., ist Sess., Report on the Use of Soctal Research in Federal Domestic Programs, pt. 4, at $486-658$ (Comm. Print 1967). This report indicates that OEO was the agency most often cited by grantees for its "interference" in their research and development work. 
of many present and future OEO programs. Thus, there will be a continuing need to balance the goals of the two organizations to ensure maximum flexibility to experiment for OFC while still maintaining a reasonable amount of direction and control over these experiments, thereby ensuring effective feedback for other OEO programs and for transfer to various operating agencies.

\section{IV}

\section{Prerequisites for Successful OFC Operation}

For successful $O F C$ operation, the organization must establish its long-term goals and must effectively communicate them to its various constituents. If it is to be a truly experimental agency in economic development, then it must seek to educate the various constituencies to this long-term orientation. These various constituencies include the CDC's, the various congressional committees, OEO, domestic affairs agencies (such as SBA, HUD, and EDA), and the investment community. OFC must avoid becoming just another operating arm of OEO or of any other agency. It must design its projects for long-term impact and work to identify appropriate methods of evaluation which will probably include social as well as economic measures of success. To minimize political pressures, several steps must be taken, such as seeking funds from sources outside OEO, both public and private; selecting a portion of the initial projects for their early, visible impact on the community; seeking to participate in the selection and evaluation criteria; and channeling most of the early projects through the CDC's.

It is likely that the results of the OFC program will be a mixed bag for the immediate future. Nevertheless, it remains the one truly experimental program available to the Administration to test a variety of capital base-building devices. It has a strong board of directors and an able president, and it can operate in a relatively independent manner. To achieve its goals OFC will have to secure sufficient funds from a variety of sources, obtain substantial community support, devise meaningful measures of the various projects undertaken, and find ways and means of transferring its results to operating agencies. 